\title{
An unusual penetrating craniocerebral injury due to landmine explosion: a case report
}

\author{
Mayın patlamasına bağlı bir sıradıșı penetran kraniyoserebral yaralanma: \\ Olgu sunumu
}

\author{
Cem ATABEY, Turgay ERSOY
}

\begin{abstract}
Penetrating landmine injuries are the unavoidable consequences of military conflicts. They are potentially lifethreatening. The mortality rates in the literature range from $23 \%$ to $92 \%$ and are considerably higher in patients admitted with poor neurologic state. Penetrating craniocerebral injuries require early surgical management designated to prevent infection and remove foreign objects, necrotic tissue and complicating blood clots, as well as to minimalize post-traumatic sequelae. We report herein an interesting case of penetrating intracerebral injury with giant shrapnel due to landmine in a 20-year-old young man.
\end{abstract}

Key Words: Craniocerebral injury; landmine; penetrating wound; shrapnel.

Penetrating craniocerebral trauma is a potentially life-threatening injury, with a $20 \%$ mortality rate. ${ }^{[1]}$ Aggressive and urgent surgical approaches can be lifesaving. ${ }^{[1-3]}$ The reported complications in these types of penetrating craniocerebral injuries, including those caused by landmines, include intracerebral hematoma, intracerebral infection, cerebrospinal fluid (CSF) fistula, epileptic seizures, and loss of mental and motor function. ${ }^{[1,3-6]}$

We present herein a 20 -year-old male with a penetrating intracerebral giant shrapnel injury due to landmine.

\section{CASE REPORT}

A 20-year-old male patient with a transcranial landmine injury was admitted to our emergency service. There was no neurological deficit. His Glasgow Coma Scale (GCS) on admission was 15 . His respi-
Penetran mayın yaralanmaları askeri çarpışmaların kaçınılmaz sonuçlarındandır. Hayatı tehdit edici potansiyelleri vardır. Literatürde mortalite oranı $\% 23$ ile $\% 92$ arasında değişmekte ve ağır nörolojik tablo ile getirilen hastalarda bu oran daha yüksektir. Penetran kafa travmalarında, oluşabilecek travma sonrası sekeli azaltabilmek amaciyla yabancı cisimleri, nekrotik beyin dokusunu, pıhtılaşmış kanamayı çıkartmak ve enfeksiyon riskinden korumak amacıyla erken cerrahi girişim gereklidir. Bu yazıda, mayın patlaması sonucu büyük şarapnel parçasıyla yaralanan 20 yaşında bir olgu sunuldu.

Anahtar Sözcükler: Kraniyoserebral yaralanma; mayın; penetran yaralanma; şarapnel.

ration rate was 16/minute. Pupils were isocoric, and bilateral direct and consensual light reflexes were equal. The international normalized ratio (INR) of the patient's prothrombin time was 1.02 . There was a lacerated wound over the right temporal region (Fig. 1). Plain X-ray of the head revealed a metallic foreign body in the right temporal region (Fig. 2). A computed tomography $(\mathrm{CT})$ scan also revealed a metallic foreign body and bone fragments in the right temporal lobe; no intracranial bleeding was demonstrated (Fig. 3).

A prophylactic antibiotic combination of cephalosporin and metronidazole (cephalosporin $3 \mathrm{~g}$ /day and metronidazole $7.5 \mathrm{mg} / \mathrm{kg}$ per day) was given, and tetanus vaccination was administered.

The patient was immediately operated. After a limited temporal craniectomy, contused necrotic brain matter was aspirated. The metallic foreign body and 


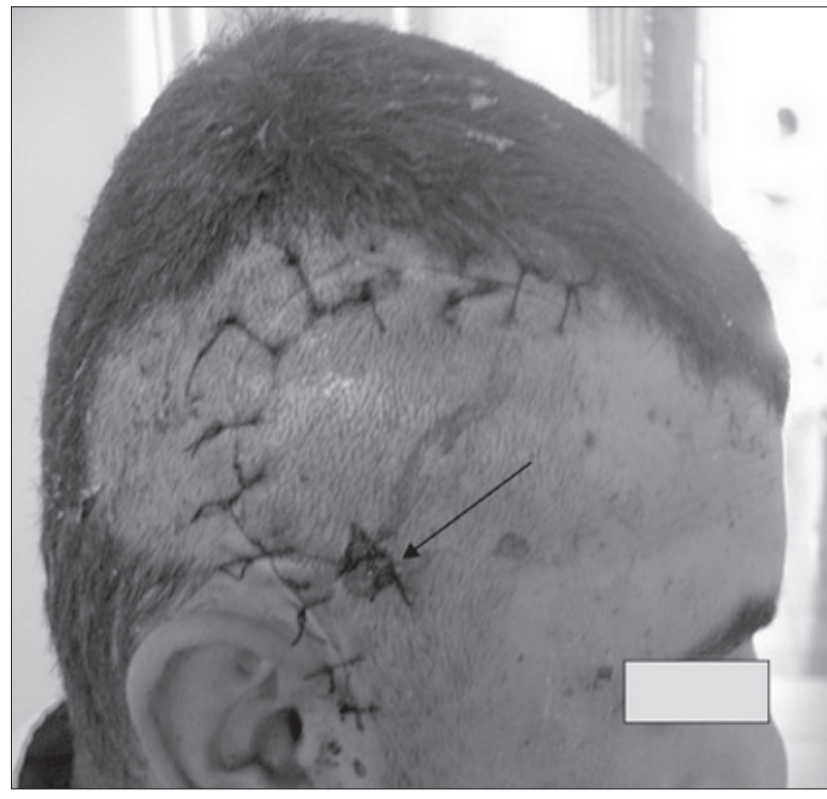

Fig. 1. Scalp laceration at the right temporal region.

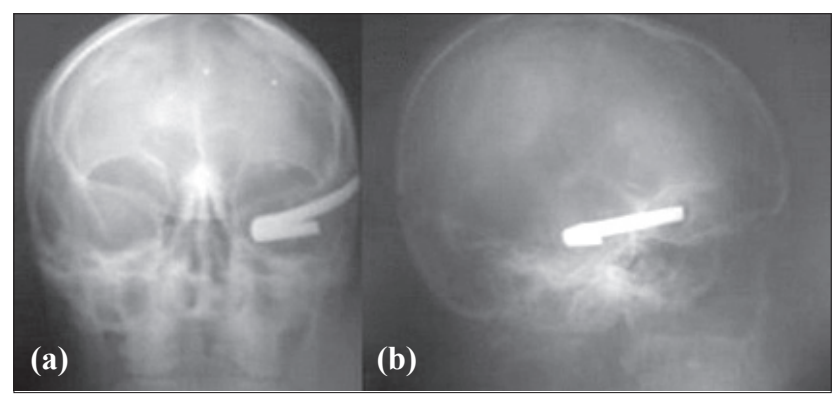

Fig. 2. Plain skull radiographs demonstrating a metallic fragment on the anteroposterior (a) and lateral (b) views.

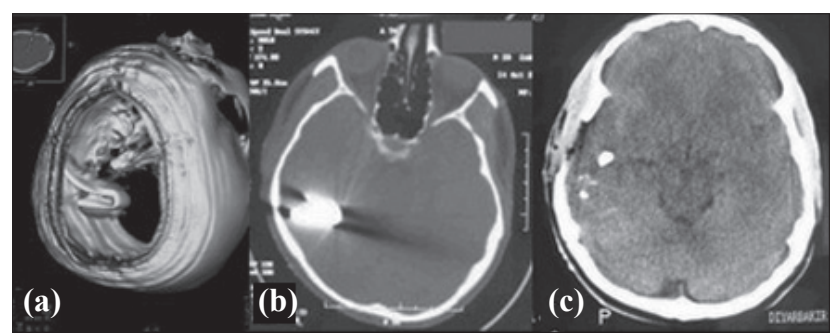

Fig. 3. Preoperative 3D CT (a) and axial CT (b) scan showing the metallic and bone fragments and axial CT scan showing the postoperative residual fragments (c).

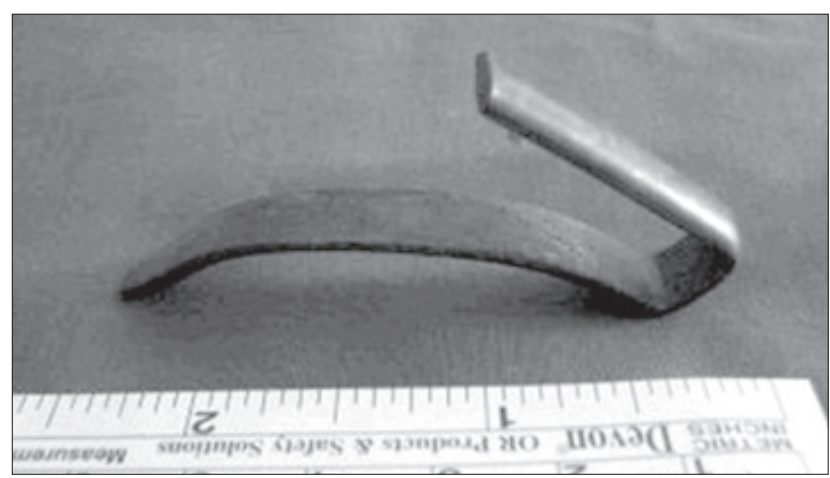

Fig. 4. Removed metallic fragment $(1 \times 6 \mathrm{~cm})$. accessible bone fragments were removed (Fig. 4). Antiepileptic and analgesic treatments were also given postoperatively. The postoperative course was uneventful, and the patient was discharged on postoperative day 7 (Fig. 5). Neither clinical nor radiological evidence of infection and/or any other complication was documented during the one-year follow-up.

\section{DISCUSSION}

Penetrating head injuries have a high morbidity and mortality rates ranging between $23 \%$ and $92 \%$, and these are considerably higher $(87 \%-100 \%)$ in patients admitted with a poor initial neurologic status. ${ }^{[7]}$ As previously reported, the most significant predictor of outcome is GCS. ${ }^{[1,7-9]}$ Other prognostic factors are hemodynamic and respiratory status on admission, pupil size and reactivity, and presence of coagulation abnormalities. ${ }^{[7,8]}$ In our case, the GCS was 15 . He had spontaneous respiration (16/minute) without any hemodynamic imbalance. His pupils were isocoric and pupillary responses to light were normal. His INR was 1.02 .

Cranial gunshot wounds can be classified as tangential, perforating or penetrating. ${ }^{[10-12]}$ Radiological assessment is important in the planning of the surgical procedure. Cranial CT scan is the most valuable method for obtaining detailed information about the injury, such as foreign body location and its relation to the adjacent structures, and for detecting metallic bodies and bone fragments as small as $0.06 \mathrm{~mm}^{3} \cdot{ }^{[5]}$ The CT scan can also identify the extension of the lesion

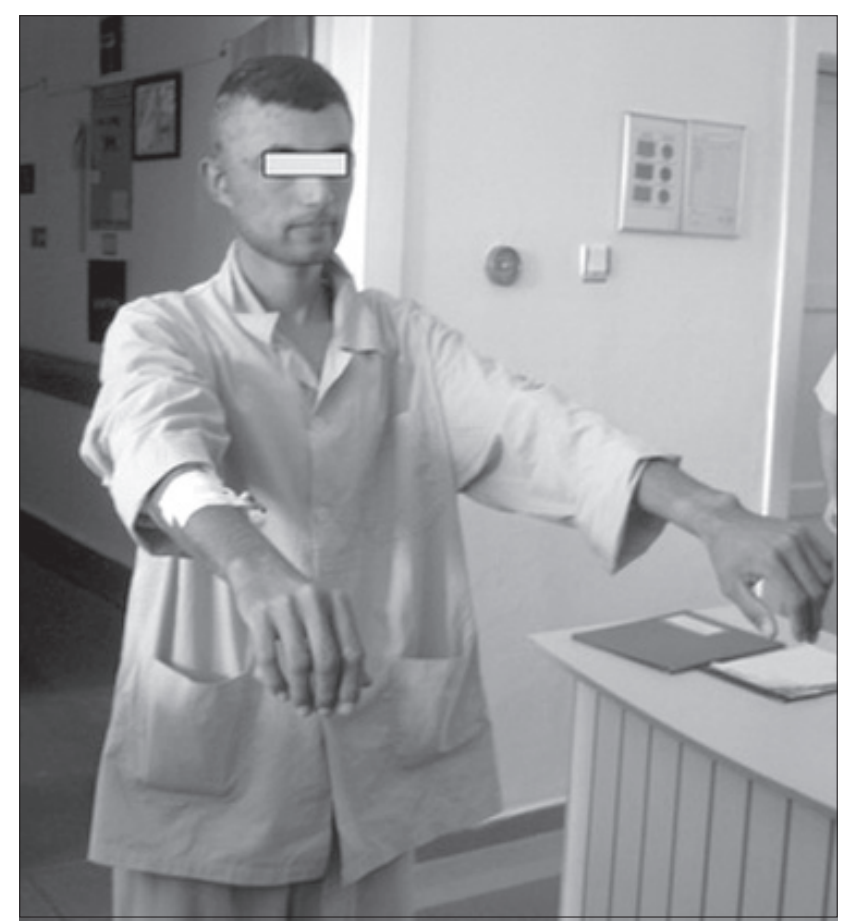

Fig. 5. The patient before discharge with no neurological deterioration. 
and presence of hematoma and/or other associated lesions, determine the missile track and provide useful information for the planning of the surgical procedure; it usually helps to define the prognosis. ${ }^{[1,2,5,10]}$ In these injuries, bilateral hemispheric injuries, multilobar injuries, the presence of transventricular trajectory or brainstem injury, intracerebral hematoma with mass effect, and the existence of foreign body (bone, missile) usually indicate an unfavorable outcome and high mortality. ${ }^{[1,6-9]}$ Magnetic resonance imaging is usually less accessible, and in the case of intracranial metallic foreign body, it is contraindicated because of the potential risk for migration and further injury. Furthermore, magnetic resonance imaging may not provide adequate imaging of the bones. Therefore, its use in gunshot injuries is limited. ${ }^{[1,3]}$

Some authors have suggested aggressive intracranial debridement in an effort to locate and remove all in-driven intraparenchymal bone and metal fragments. ${ }^{[2,13]}$ However, this aggressive procedure may be associated with severe neurological deficit. Kim et al. ${ }^{[1]}$ advocated a less aggressive surgical approach, consisting of minimal local debridement, preserving as much cerebral tissue as possible, and easy removal of the bone and metal fragments. They also reported that there was no correlation between the presence of retained fragments and subsequent development of intracranial infection or epilepsy. With the use of CT scanning, it is now possible to diagnose the extension of cerebral injury and to locate the hematoma, bone and/or shrapnel fragments accurately within the brain. ${ }^{[13]}$ In our case, we preferred a minimally invasive approach; accessible bone fragments and foreign material were removed and necrotic brain tissues were evacuated. Following the bleeding control, the dura mater was repaired with temporal fascia to prevent CSF leakage. ${ }^{[14]}$

The morbidity rates range between $8 \%$ and $20 \%$. ${ }^{[1,12]}$ Intracerebral infection, CSF fistula, epileptic seizures, and loss of mental and motor function due to severe damage to the brain parenchyma are the common complications..$^{[1,3-6,15]}$ Among them, infection is the most important complication. Rish et al. ${ }^{[16]}$ suggested that intracranial infection is the most common complication of penetrating missile injuries to the brain. Intracerebral infection occurred in 3 to $17 \%$ of all cases, generally forming within one to five weeks after the injury. The mortality rate of patients with infection has been reported to exceed $50 \% \cdot{ }^{[17]}$ If CSF leakage occurs, especially longer than 24 hours, patients should be operated and dural repair performed to avoid possible complications such as meningitis and ventriculitis. ${ }^{[15]}$ Tetanus vaccination and antibiotic prophylaxis are also mandatory medications in the management of these patients. ${ }^{[18]}$ In our patient, there was no infection, CSF fistula, or epileptic seizure during the one-year follow-up period.

In the management of cranial injuries secondary to landmine explosion, all patients (asymptomatic or symptomatic) must be evaluated with CT scans. However, because of intracerebral foreign bodies, less aggressive surgery is essential, as in our case.

In conclusion, penetrating craniocerebral injuries have a high morbidity and mortality rate. Patients require immediate radiological and clinical assessment. Early and adequate less aggressive surgical management with appropriate antibiotherapy with tetanus vaccination in the perioperative period may provide a better outcome. A long-term radiological assessment should be performed to detect any future complications, such as a suppurative abscess.

\section{REFERENCES}

1. Kim TW, Lee JK, Moon KS, Kwak HJ, Joo SP, Kim JH, et al. Penetrating gunshot injuries to the brain. J Trauma 2007;62:1446-51. CrossRef

2. Brandvold B, Levi L, Feinsod M, George ED. Penetrating craniocerebral injuries in the Israeli involvement in the Lebanese conflict, 1982-1985. Analysis of a less aggressive surgical approach. J Neurosurg 1990;72:15-21. CrossRef

3. Gönül E, Erdoğan E, Taşar M, Yetişer S, Akay KM, Düz B, et al. Penetrating orbitocranial gunshot injuries. Surg Neurol 2005;63:24-31. CrossRef

4. Civelek E, Bilgiç S, Kabataş S, Hepgül KT. Penetrating transorbital intracranial foreign body. Ulus Travma Acil Cerrahi Derg 2006;12:245-8.

5. Satyarthee GD, Borkar SA, Tripathi AK, Sharma BS. Transorbital penetrating cerebral injury with a ceramic stone: report of an interesting case. Neurol India 2009;57:331-3. CrossRef

6. Splavski B, Vranković D, Sarić G, Saftić R, Maksimović Z, Bajek G, et al. Early surgery and other indicators influencing the outcome of war missile skull base injuries. Surg Neurol 1998;50:194-9. CrossRef

7. Martins RS, Siqueira MG, Santos MT, Zanon-Collange N, Moraes OJ. Prognostic factors and treatment of penetrating gunshot wounds to the head. Surg Neurol 2003;60:98-104.

8. Nathoo N, Chite SH, Edwards PJ, van Dellen JR. Civilian infratentorial gunshot injuries: outcome analysis of 26 patients. Surg Neurol 2002;58:225-33. CrossRef

9. Stone JL, Lichtor T, Fitzgerald LF. Gunshot wounds to the head in civilian practice. Neurosurgery 1995;37:1104-12. CrossRef

10. Izci Y, Kayali H, Daneyemez M, Koksel T, Cerrahoglu $\mathrm{K}$. The clinical, radiological and surgical characteristics of supratentorial penetrating craniocerebral injuries: a retrospective clinical study. Tohoku J Exp Med 2003;201:3946. CrossRef

11. Izci Y, Kayali H, Daneyemez M, Koksel T. Comparison of clinical outcomes between anteroposterior and lateral penetrating craniocerebral gunshot wounds. Emerg Med J 2005;22:409-10. CrossRef

12. Secer HI, Gonul E, Izci Y. Head injuries due to landmines. Acta Neurochir (Wien) 2007;149:777-82. CrossRef

13. Chaudhri KA, Choudhury AR, al Moutaery KR, Cybulski GR. Penetrating craniocerebral shrapnel injuries during "Operation Desert Storm": early results of a conservative surgical 
treatment. Acta Neurochir (Wien) 1994;126:120-3. CrossRef

14. Singh P. Missile injuries of the brain: results of less aggressive surgery. Neurol India 2003;51:215-9.

15. Bhatoe HS. Retained intracranial splinters : a follow up study in survivors of low intensity military conflicts. Neurol India 2001;49:29-32.

16. Rish BL, Dillon JD, Weiss GH. Mortality following penetrating craniocerebral injuries. An analysis of the deaths in the Vietnam Head Injury Registry population. J Neurosurg 1983;59:775-80. CrossRef

17. Taha JM, Haddad FS, Brown JA. Intracranial infection after missile injuries to the brain: report of 30 cases from the Lebanese conflict. Neurosurgery 1991;29:864-8. CrossRef

18. Coupland RM, Korver A. Injuries from antipersonnel mines: the experience of the International Committee of the Red Cross. BMJ 1991;303:1509-12. CrossRef 